Int. J. Dev. Biol. 51: 117-122 (2007)

doi: $10.1387 / \mathrm{ijdb} .062187 \mathrm{mh}$

Original Article

\title{
NMDA-receptor blockade enhances cell apoptosis in the developing retina of the postnatal rat
}

\author{
MARÍA HERNÁNDEZ ${ }^{1}$, INMACULADA GUERRIKAGOITIA² ${ }^{2}$ LUIS MARTÍNEZ-MILLAN² and ELENA VECINO*,1 \\ ${ }^{1}$ Department of Cell Biology and ${ }^{2}$ Departament of Neuroscience, Faculty of Medicine, University of the Basque Country, \\ Leioa, Vizcaya, Spain
}

\begin{abstract}
During visual system development, programmed cell death occurs in order to facilitate the establishment of correct connections and synapses. During this period, glutamate plays a very important role as an excitatory neurotransmitter. With a view to evaluating if NMDA glutamate receptors participate in the regulation of apoptosis which occurs during the development of the rat retina, we subcutaneously injected the NMDA receptor antagonist MK-801 into rats at different stages of early postnatal development (P2 to P9). Ensuing cell death in the retina and superior colliculus was analyzed by using the Feulgen method. MK-801 administration had no effect on the survival of photoreceptor cells. In contrast, the presence of this antagonist induced a significant increase in the number of apoptotic cells in the neuroblastic layer (P7 and P8) and ganglion cell layer (P6-P8), as well as in the superior colliculus which receives afferent contacts from retinal ganglion cells during P7-P9. We conclude that during development, specific types of cells in the mammalian retina are critically dependent for their survival on glutamate stimulation through NMDA receptors. These findings thus throw fresh light on the mechanisms of development of the rat visual system by identifying NMDA glutamate receptors as participants in the regulation of apoptotic processes which occur during the initial stages of development.
\end{abstract}

KEY WORDS: apoptosis, retina, glutamate receptor, retinal ganglion cell, MK-801, NMDA

\section{Introduction}

The newborn rat retina is organized into two layers: the innermost cellular stratum is known as the ganglion cell layer (GCL) which contains retinal ganglion cells (RGCs) and displaced amacrine cells and the outer cellular stratum which is known as the neuroblastic layer (NBL). At later stages of development, the inner part of the NBL (future inner nuclear layer) contains differentiating amacrine cells and a single row of horizontal, bipolar and Müller cells. The outer part of the NBL (future outer nuclear layer) is made up of a layer of photoreceptors undergoing differentiation. Towards adulthood, the NBL becomes laminated into two nuclear and two plexiform layers.

During retinal development, different cell types are produced and migrate to their corresponding layer where they differentiate and form appropriate synaptic connections. RGCs project to the superior colliculus and pretectal nuclei (Dreher et al., 1985). The majority of RGCs project contralaterally; thus in albino rats, less than $1 \%$ of the total RGC population located in the temporal retina projects to the ipsilateral superior colliculus.

Apoptosis or programmed cell death (PCD) represents the most common mechanism to regulate cell number during visual system development. It has been demonstrated that during the first 10 postnatal days in the rat, around $50 \%$ of newly generated RGCs die after reaching their targets (Perry et al., 1983). This represents a large underestimation of RGC elimination, since the migration of newly generated RGCs to their layer occurs over several days and many RGCs die before they reach their definitive location in the retina. Thus, it has been estimated by studying the elimination of RGCs generated at defined embryonic stages, that as many as $90 \%$ of RGCs die during the first postnatal week in rats (Galli-Resta and Ensini, 1996). The extent of apoptotic death in other retinal cell populations during development has not been precisely estimated to date. However, the relatively low number of photoreceptor cells observed with degenerating profiles indicates that during rat postnatal development, PCD does not affect this cell population very much (Vogel and Möller, 1980).

In the rodent superior colliculus, PCD is also important for the

Abbreviations used in this paper: GCL, ganglion cell layer; INL, inner nuclear layer; NBL, neuroblastic layer; ONL, outer nuclear layer; PCD, programmed cell death; RGC, retinal ganglion cell.

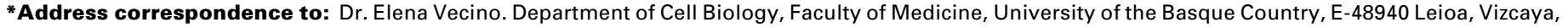
Spain. Fax: +34-94-601-3266. e-mail: elena.vecino@ehu.es
} 


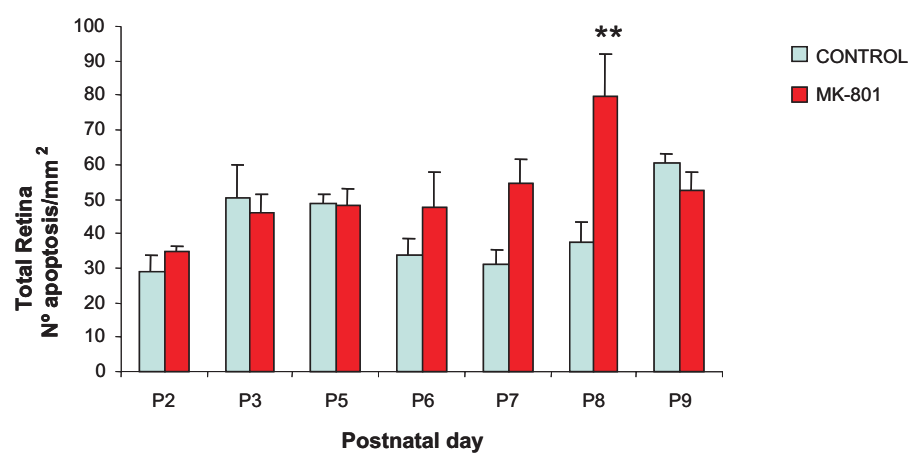

Fig. 1. Effect of MK-801 on cell apoptosis in the total retina at different postnatal stages. Values are mean \pm SEM and are expressed as number of apoptotic cells per $m^{2}{ }^{2}{ }^{*}{ }^{*} p<0.01$, significant differences with respect to control.

completion of appropriate RGC projections. It has been shown that restriction of the transient ipsilateral projection to the superior colliculus is achieved by preferential elimination of ipsilaterally projecting RGCs during the period of naturally occurring cell death (Insausti et al., 1984).

Intrinsic cell death programs seem to be activated by the absence of trophic support and by cell competition for limited synaptic space (Galli-Resta and Resta, 1992; Martin etal., 1996). Moreover, other factors such as neurotransmitters seem to regulate apoptosis during development. Neurotransmitters are present in the retina during early stages of development when synapses are still not present (Redburn and Rowe-Rendleman, 1996). The neurotransmitter glutamate, which is the main excitatory neurotransmitter in the vertebrate retina (Massey, 1990; Bodnarenko et al., 1995), is involved in processes such as differentiation, migration, maturation, cell motility and neurite outgrowth during development (Lauder, 1993). Glutamate is a survival factor for both differentiating and proliferating cells in the developing retina. In this sense, it has been shown that the protective effect of glutamate against cell death is mediated by NMDA receptors and depends on neurotrophic factors such as BDNF and its receptor TrKB (Rocha et al., 1999; Martins et al., 2005).

The glutamate receptor family is made up of two main groups of receptors: the ionotropic glutamate receptors, which are ligand gated ion channels sensitive to $\mathrm{N}$-methyl-D-aspartate (NMDA receptors) and $\alpha$-amino-3-hydroxy-5-methyl-4-isoxasole-propionate (AMPA/kainate receptors); and the metabotropic glutamate receptors which act through second messenger systems (Hollmann and Heinemann, 1994; Mori and Mishina, 1995). NMDA receptors are hetero-oligomeric channels composed of different subunits: NR1, NR2A-D (Laube, 1998; Rosenmund et al., 1998) and NR3A (Ciabarra et al., 1995; Wong et al., 2002). Assembly of a functional receptor requires the presence of an NR1 subunit and one or more NR2 subunits (NR2A, NR2B, NR2C and NR2D). NMDA receptor subunits show distinct distribution patterns in synaptic layers and also among the various retinal cell types, suggesting that different types of heteromeric glutamate receptors exist at all levels of retinal information processing and that they are differentially distributed during development. For example, rod bipolar cells do not express the NR1 subunit, which is thought to be essential to form functional NMDA receptors, nor the NR2B subunit in the tissue which will make up the future outer nuclear layer (ONL) until postnatal day 9 (Gründer et al., 2000). In the rat brain, the composition of NMDA receptors is also developmentally regulated, such that NR2B subunits are highly expressed in the forebrain and midbrain of juveniles, whereas NR2A-containing receptors predominate in adulthood (Watanabe et al., 1992; Monyer et al., 1994).

MK-801 is an NMDA receptor antagonist which prevents signal transmission by means of the blockade of NMDA receptor ion channels. Application of MK-801 both locally, in the developing rat retina and systemically leads to alteration of the topographic retino-collicular projection (Simon etal., 1992) and modification of the pattern of RGC death. Thus, in normal development, apoptosis is mainly observed in the RGCs which project erroneously to the superior colliculus (Crespo et al., 1985), whereas after MK-801
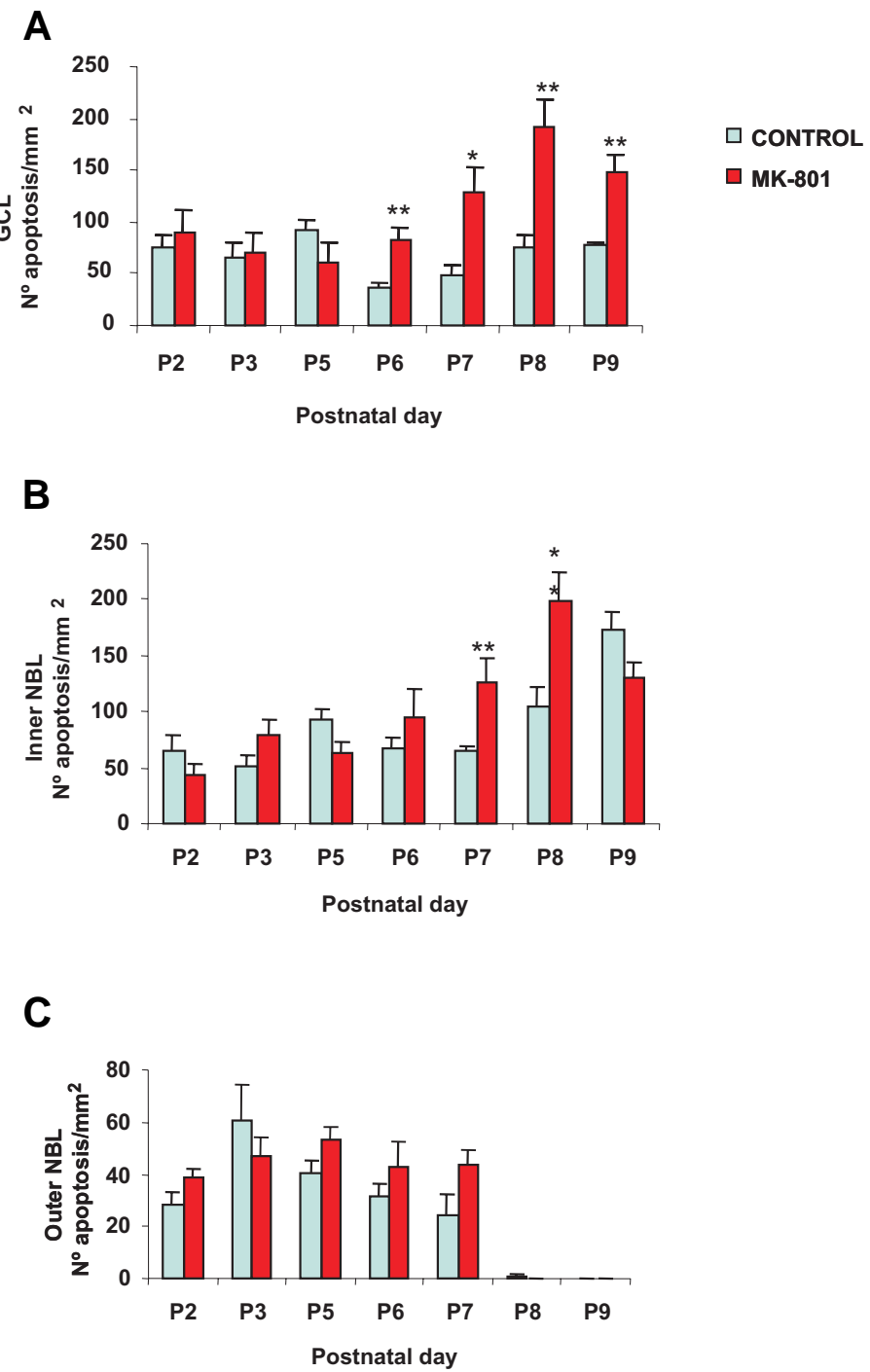

Fig. 2. Effect of MK-801 on cell apoptosis in the different retinal cell layers at different postnatal stages. Apoptosis in (A) ganglion cell layer (GCL), (B) inner neuroblastic layer (NBL) and (C) outer neuroblastic layer. Values represent means \pm SEM and are expressed as number of apoptotic cells per $\mathrm{mm}^{2}$. ${ }^{*} p<0.05$ and ${ }^{*}{ }^{*} p<0.01$, significant differences with respect to control. 
administration, RGC death is not only observed in these cells, but also in RGCs which have projected to the right place in the superior colliculus (Cline and Constantine-Paton, 1989). On the other hand, ethanol can antagonize NMDA receptors and exert GABA mimetic effects (Lovinger at al., 1989; Hoffman etal., 1989) by interfering with major neurotransmitter systems during critical periods of development. In this sense, ethanol can cause apoptosis in neurons, when coinciding with the period of synaptogenesis (Dobbing and Sands, 1979). For example, during visual system development in postnatal rats and mice, ethanol triggered degeneration of neurons in the GCL (Stromland and Pinazo-Duran, 1994) and in the lateral geniculate nucleus, superior colliculus and visual cortex of the brain (Tenkova et al., 2003). As well as ethanol, memantine is a neuroapoptotic drug which blocks NMDA glutamate receptors and it has been reported to exert a toxic effect on RGCs when administrated to neonatal mice (Nardi et al., 2004).

A variety of studies have examined the effect of antagonism of NMDA receptors in the mammalian visual system on the establishment of visual projections and connections in the postnatal rat superior colliculus, (Bunch and Fawcett, 1993), on retinogeniculate afferents in ferret kittens (Hahm et al., 1991; Hahm et al., 1999) and in the prevention of ocular dominance plasticity in the kitten visual cortex (Bear et al., 1990) among others. However, the effect of NMDA blockade in the different layers of the retina at different postnatal days during development is currently unknown. Thus, in the present study we analyzed and quantified the apoptotic effect of NMDA receptor antagonism on the different populations of retinal cells at different stages of development (P2 to P9) of the rat retina. Also we analyzed apoptosis occurring during the development of the rat superior colliculus in order to examine the effect of target cell death on RGC survival. The present results demonstrate that blockade of NMDA receptors with the antagonist MK-801 produces an increase in apoptosis during the early development of the retina. This increased apoptosis is evident in all of the layers of the retina, with the exception of the layer of photoreceptors and affected RGC target cells in the superior colliculus.

\section{Results}

\section{Apoptosis in the retina after MK-801 treatment}

MK-801 produced an increase in the number of apoptotic cells in the total retina. This increase $(116 \%)$ was statistically significant $(p<0.01)$ at P8 $\left(80 \pm 12\right.$ cell $/ \mathrm{mm}^{2}$ vs. $37 \pm 5$ cell $/ \mathrm{mm}^{2}$, MK801 and control respectively) (Fig. 1).

In the GCL, the increase in the number of apoptotic cells in response to MK-801 treatment was statistically significant $(p<$ 0.01 ) at stages P6 (128\% increase; $82 \pm 12$ cell $/ \mathrm{mm}^{2}$ vs. $36 \pm 5$ cell $/ \mathrm{mm}^{2}$, MK-801 and control, respectively), P7(169\% increase; 129 \pm 24 cell $/ \mathrm{mm}^{2}$ vs. $48 \pm 11$ cell $/ \mathrm{mm}^{2}$, MK-801 and control respectively), P8 (151\% increase; $191 \pm 83$ cell / $\mathrm{mm}^{2}$ vs. $76 \pm$ 11 cell $/ \mathrm{mm}^{2}$, MK-801 and control respectively) and P9 (101\% increase; $149 \pm 15 \mathrm{cell} / \mathrm{mm}^{2}$ vs. $74 \pm 2 \mathrm{cell} / \mathrm{mm}^{2}, \mathrm{MK}-801$ and control respectively) (Figs. $2 \mathrm{~A}$ and 3 ).

In the inner NBL, which is the prospective INL, MK-801 caused a significant increase $(p<0.01)$ in the number of apoptotic cells at P7(95\% increase; $127 \pm 21$ cell / $\mathrm{mm}^{2}$ vs. $65 \pm 4$ cell / $\mathrm{mm}^{2} \mathrm{MK}$ 801 and control, respectively) and at P8 (92\% increase; $200 \pm 23$

\section{CONTROL}

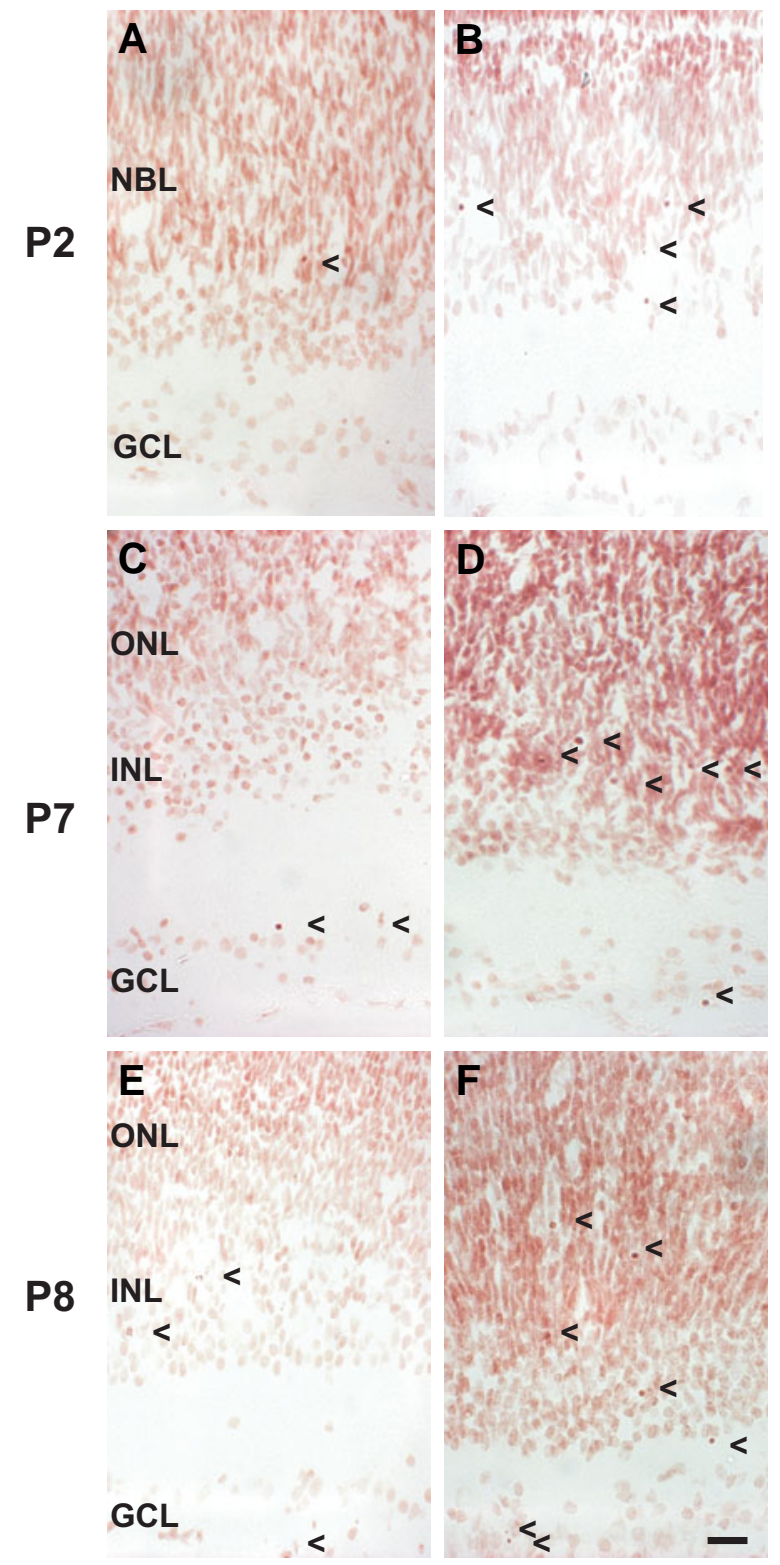

Fig. 3. Histology of rat retinas at different stages of development following eight hours of exposure to MK-801. Apoptotic cells were visualized by Feulgen staining. (A,C,E) Control retinas from rats at postnatal stages $P 2, P 7$ and $P 8$ respectively. (B,D,F) Retinas from rats at postnatal stages $P 2, P 7$ and $P 8$ treated with $M K-801$. MK-801 leads to an increase in the amount of apoptotic cells in the retina at these developmental stages. Arrows point to apoptotic retinal cells. Scale bar, $100 \mu \mathrm{m}$. Abbreviations: $G C L$, ganglion cell layer; INL, inner nuclear layer; $N B L$, neuroblastic layer; ONL, outer nuclear layer.

cell / mm² vs. $104 \pm 17$ cell $/ \mathrm{mm}^{2}$, MK-801 and control respectively, $p<0.01)$. However, we did not observe any effect of MK801 on the number of apoptotic cells at P9 (Fig. 2B).

Analyzing apoptosis occurring in each retinal layer, we found that in the outer NBL, future ONL (where photoreceptor cells are undergoing differentiation), apoptosis occurred from stages P2 


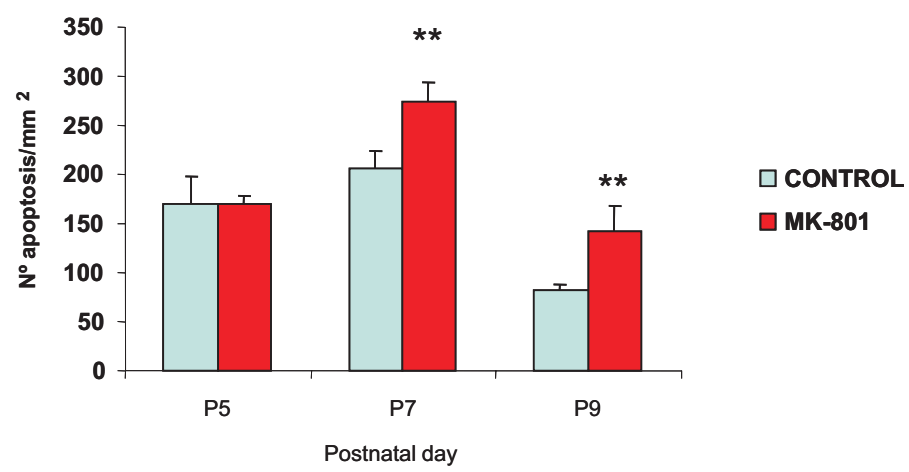

Fig. 4. Effect of MK-801 on cell apoptosis in the superior colliculus at postnatal stages P5, P7 and P9. The area analyzed comprises the stratum optic (SO) and superficial grey substrate (SGS). Values are mean \pm SEM and are expressed as number of apoptotic cells per $\mathrm{mm}^{2} .{ }^{*} p<0.05$ and ${ }^{*} p<0.01$.

(39 \pm 3 cell $/ \mathrm{mm}^{2}$ vs. $28 \pm 4$ cell $/ \mathrm{mm}^{2}$, MK- 801 and control respectively $p<0.01)$ to $P 7\left(44 \pm 4\right.$ cell $/ \mathrm{mm}^{2} \mathrm{vs}$. $24 \pm 7$ cell $/ \mathrm{mm}^{2}$ MK-801 and control respectively $p<0.01$ ), but was not significantly enhanced by MK-801. No cells with an apoptotic appearance were observed in the ONL from P8 onwards (Fig. 2C).

Apoptosis in the superior colliculus after MK-801 treatment

Apoptosis in the superior colliculus was examined using the Feulgen method in control and MK-801-treated animals at developmental stages P5, P7 and P9, because these stages include the most important period of RGC death by apoptosis and we wanted to study the effect of target cell death on RGC survival. The number the apoptotic cells at stage P5 in the control superior colliculus was $169 \pm 28 \mathrm{cell} / \mathrm{mm}^{2}$. This value was not significantly modified by MK-801 (170 \pm 9 cell / mm²). However, MK-801 led to a significant increase $(p<0.01)$ in the density of apoptotic cells in the superior colliculus at P7 ( $33 \%$ increase; $274 \pm 19$ cell / $\mathrm{mm}^{2}$ vs. $206 \pm 17 \mathrm{cell} / \mathrm{mm}^{2}, \mathrm{MK}-801$ and control respectively) and at P9 (82\% increase; $149 \pm 9$ cell $/ \mathrm{mm}^{2}$ vs. $82 \pm 4$ cell $/ \mathrm{mm}^{2}$, MK801 and control respectively) $(p<0.01)$ (see Fig. 4).

\section{Discussion}

In the present study, we analyzed the effect of NMDA receptor antagonism on the apoptosis of different cell populations in the retina and superior colliculus during rat postnatal development. NMDA receptors are expressed in the superior colliculus (Watanabe et al., 1992; Monyer et al., 1994) and distinct types of NMDA receptors are known to be differentially expressed in horizontal cells, amacrine cells and RGCs (Gründer et al., 2000). Indeed, there receptors are expressed early in the visual system and as a consequence, NMDA receptors are thought to be associated with plasticity processes during the formation of retinal circuitry (Weidman and Kuwara, 1969; Hermes etal., 1992). Here we report how NMDA receptor antagonism differentially enhances the apoptosis of different cell types in the developing retina.

MK-801 administration was found to increase programmed cell death in the retina. However, not all cell types were affected to the same degree. Some cells, such as RGCs are particularly affected following MK-801 treatment. Thus, we observed a significant increase in the apoptosis of cells in the GCL during the P6 to P9 stages, with a peak of maximum death around P8. This increased death may be a consequence of enhanced death of the target cells in the superior colliculus which receive RGC projections. In order to verify this possibility, we analyzed the death of cells in zones of the superior colliculus which receive retinal afferents, at stages P5, P7 and P9. We show that MK-801 administration produces a large increase in the number of apoptotic cells during P7 in the zone comprising the optic stratum (OS) and the superficial grey stratum (SGS) of the superior colliculus. Since we observed a massive loss of cells in the GCL during P8, it is possible that this happens in response to the death of their target cells, via a mechanism known as «retrograde transneuronal degeneration» (Perry and Cowey, 1979).

It is interesting to note that during the first days of postnatal development, the death of RGC target cells in the superior colliculus appears to occur one day before the maximum peak of RGC death in the retina; thus, during postnatal development of the rat retina, the interruption of synaptic contact and consequently of the passage of neurotrophic and survival factors between superior colliculus cells and RGCs may provoke an increase in cell apoptosis in the ganglion cell layer of the retina. This finding demonstrates the importance of establishing synaptic connections between cells of the visual system, particularly during the initial stages of development.

Some authors have suggested that the effect of MK-801 on the fine tuning of rat visual projections is produced via blockade of NMDA receptors in the superior colliculus, rather than directly via RGCs (Bunch and Fawcett, 1993). However, it is known that RGCs express NMDA receptors from the first weeks of development (Gründer et al., 2000) and that glutamate is one of the most abundant excitatory neurotransmitters in the retina (Nicoletti et al., 1996). Thus, the increase in apoptosis in the GCL following MK-801 administration is likely to also involve a direct action of the antagonist on NMDA receptors in the retina. In this sense, it has been shown that the survival of neonatal rat RGCs in vitro depends on glutamate, since glutamate is involved in the regulation of electrical activity of developing rat RGCs (Govindaiah et al., 2002).

The present results indicate that MK-801 administration induces an increase in apoptosis in the NBL, between stages P7 and P8. Of the cells which make up this layer, horizontal cells and amacrine cells express functional NMDA receptors during these stages of development (Gründer et al., 2000), Thus, MK-801 may provoke cell death in this layer via direct blockade of NMDA receptors. Nevertheless, other possibilities should also be considered. Thus, it has been shown that RGCs present spontaneous electrical activity during embryonic stages of development (Weidman and Kuwabara, 1968; Kuwabara and Weidman, 1974; Maffei and Galli-Resta, 1990). This spontaneous activity is known to be essential for the topographic fine-tuning of RGC projections. We found that a significant increase in apoptosis in the NBL takes place between $P 7$ and $P 8$. This increase is subsequent to the death of RGCs in P6 raising the possibility that cell death in outer layers of the retina may be due in part to the prior death of RGCs.

MK-801 was not found to have any significant effect on the apoptosis of photoreceptors during any of the different stages analyzed. It has been reported that some subunits of glutamate 
receptors, such as $\mathrm{NR} 2 \mathrm{~B}$, are not expressed in this cell layer until stages subsequent to P9 (Gründer et al., 2000). The absence of this subunit, which could be essential for the functionality of the receptor, may explain why MK-801 does not alter the process of apoptosis in photoreceptors during the analyzed developmental periods and hints at strategies for blocking apoptosis in retinal pathologies involving excessive cell loss.

In summary, the present study demonstrates that the blockade of NMDA receptors during early postnatal rat development induces increased apoptosis in different retinal cell types, with the exception of photoreceptors, indicating that glutamate, via NMDA receptors, plays an important role in the regulation of apoptotic processes which take place during the development of the retina. Moreover, NMDA receptor blockade also enhances apoptosis in the superior colliculus; thus, increased death of these RGC target cells may contribute to the enhanced death in cells of the GCL seen one day later. We have analyzed cell death induced by NMDA receptor blockade during the first postnatal days in the different retinal layers and the present findings confirm the importance of this neurotransmitter for the correct establishment of visual circuitry during development, both at the level of the retina as well as in the superior colliculus. Overall, these findings may have relevance to human retinal and neurodevelopmental diseases associated with postnatal exposure to drugs which affect NMDA receptors, such as alcohol as well as ketamine and nitrous oxide, two NMDA antagonists used in anesthesia.

\section{Materials and Methods}

\section{Animal handling}

Fifty six postnatal Sprague-Dawley rats from 3 different litters were used in the present study. Newborn animals were considered P0 (postnatal day zero). According to Ikonomidou et al. (1999), the apoptosis triggered by MK-801 in the developing brain was high between P0 and P3 and increased further between P3 and P7. Thus, in order to cover the critical postnatal stages, we analyzed the remaining postnatal days, P2, P3, P5, P6, P7, P8 and P9. P4 rats were not used in this study since the corresponding litters were very large and the animals were consequently of low weight. Five experimental and 3 control animals from each stage of development were analyzed. Experimental animals were treated with MK-801 (0.5 mg per kilogram of body weight, subcutaneous) at 8,16 and $24 \mathrm{~h}$ before anesthesia with $7 \%$ chloral hydrate $(0.42 \mathrm{mg} / \mathrm{g}$ body weight). Thus, to analyze for example postnatal day 2 cases, we treated the animals at P1 by injecting them three times (every 8 hours) before sacrifice at P2. The protocol was identical for all other studied postnatal stages. Control animals were equivalently injected with saline solution. P2, P3 and P5 rats were beheaded, whereas $\mathrm{P} 6, \mathrm{P} 7, \mathrm{P} 8$ and $\mathrm{P} 9$ rats were perfused through the ascending aorta with $0.9 \% \mathrm{NaCl}$ followed by $4 \%$ paraformaldehyde in $0.1 \mathrm{M}$ phosphate-buffered saline (PBS).

\section{Tissue preparation}

Brains and eyes were dissected out. Eye cups made up of retina, choroids and sclera were prepared. The lenses were removed to facilitate cutting of the sections. This tissue was then fixed for three hours with $4 \%$ paraformaldehyde in PBS and subsequently cryoprotected in $30 \%$ sucrose for 12 hours at $4{ }^{\circ} \mathrm{C}$, embedded with Tissue Tek (Leica, Heidelberg, Germany) inside and around the eye cup and frozen in liquid nitrogen. Retinas from each stage of development in the control and treated groups were dorsoventrally sectioned at the level of the optic nerve at $14 \mu \mathrm{m}$ using a cryostat. Six $60 \mu \mathrm{m}$ coronal sections of the superior colliculus were cut using a cryotome.
Sections from the superior colliculus and retina were collected onto gelatinized slides and stored at $-20^{\circ} \mathrm{C}$ until they were analyzed.

\section{Detection of apoptosis}

Retinal and collicular sections were assessed by the Feulgen method. This method, a classical histochemical technique based on the staining of DNA, has been demonstrated to yield more complete information about the number of apoptotic cells as it is possible to stain the different phases of the cell death in contrast to other techniques which are more restrictive (Vecino et al., 2004). Six retinal sections from each stage of development (P2, P3, P5, P6, P7, P8 and P9), together with six collicular sections at stages P5, P7 and P9 were obtained from control and MK-801 treated animals. After rehydration, sections were exposed to $1 \mathrm{~N} \mathrm{HCl}$ at $60^{\circ} \mathrm{C}$ for 8 minutes. Then, sections were washed in distilled water and exposed to a Schiff reagent (in this case, an aqueous solution of Cresyl-violet and sulphurous acid used to detect the presence of aldehydes) for 1 hour in darkness at room temperature. The sections were washed in sulfurous water ( $10 \%$ sodium metabisulfite in distilled water), dehydrated and coverslipped. These sections were examined using an optic microscope (Axiolab, Zeiss).

\section{Counting methods}

In order to estimate the extent of apoptosis, images of the whole retina and collicular sections were captured using a digital camera (Coolsnap, RS Photometrics, Tucson, USA) coupled to a microscope. In the superior colliculus, we measured two areas: the stratum opticum (SO) and the stratum griseum superficiale (SGS) to which RGCs project. Apoptotic cells per $\mathrm{mm}^{2}$ were counted in these areas. In the retina, we identified the inner NBL (future inner nuclear layer), the outer NBL (future outer nuclear layer) and the GCL on the basis of their histomorphology. The outer NBL being identified as a layer of elongated cells and the inner NBL being identified as a layer of more rounded cells. Measurements from each section were performed directly on the computer screen by using a digital pallet (Easypen, Genius) and Spot software (Diagnostic Instruments Inc, Sterling Heigfts, MI).

\section{Statistical analysis}

The mean number of apoptotic cells / $\mathrm{mm}^{2}$ was calculated for each developmental stage using six adjacent retinal and collicular sections for each treatment group. We used SPSS software (SPSS Sciences, Chicago, IL) and the ANOVA test followed by the Scheffé test in order to compare the number of apoptotic cells among the different retinas and the different superior colliculus sections at the same stage. Comparison of the results obtained for control and MK-801 treated animals at each stage was performed by using the Student $t$ test. The minimum level of significance was defined as $p<0.05$.

\section{Acknowledgements}

Ministry of Science and Technology (BFI 2003-07177), University of the Basque Country (00077.327-15350/2003), ONCE, Fundaluce and The American Glaucoma Foundation (TGF).

\section{References}

BEAR, M., KLEINSCHMIDT, A. GU, Q.A. and SINGER, W. (1990). Disruption of experience-dependent synaptic modifications in striate cortex by infusion of an NMDA receptor antagonist. J Neurosci. 10: 909-925.

BODNARENKO, S.R., JEYARASASINGAM, G. and CHALUPA, L.M. (1995). Development and regulation of dendritic stratification in retinal ganglion cells by glutamate-mediated afferent activity. JNeurosci. 11:7037-7045.

BUNCH, S.T. and FAWCETT, J.W. (1993). NMDA receptors blockade alters the topography of naturally occurring ganglion cell death in the rat retina. Dev Biol. 160: 434-442.

CIABARRA, M., SULLIVAN, J.M., GAHN, L.G., PECHT, G., HEINEMANN, S. and SEVARINO, K.A. (1995). Cloning and characterization of $\chi-1$ : a developmen- 
tally regulated member of a novel class of ionotropic glutamate receptor family. $J$ Neurosci. 15:6498-6508.

CLINE, H.T. and CONSTANTINE-PATON, M. (1989). NMDA receptor antagonists disrupt the retinotectal topographic map. Neuron. 3:413-426.

CRESPO, D., O'LEARY, D.M. and COWAN, W.M. (1985). Changes in the numbers of optic nerve fibers during late prenatal and postnatal development in the albino rat. Brain Res. 351:129-134.

DOBBING, J. and SANDS, J. (1979). Comparative aspects of the brain growth spurt. Early Hum Dev. 3:79-83.

DREHER, B., SEFTON, A.J., NI, S.Y., NISBETT, G. (1985). The morphology, number, distribution and central projections of Class I retinal ganglion cells in albino and hooded rats. Brain Behav. Evol. 26:10-48.

GALLI-RESTA, L. and RESTA, G. (1992). A quantitative model for the regulation of naturally occurring cell death in the developing vertebrate nervous system. $J$ Neurosci. 12:4586-4594.

GALLI-RESTA, L. and ENSINI, M. (1996). An intrinsic time limit between the genesis and death of individual neurons in the developing retinal ganglion cell layer. J Neurosci. 16:2318-2324.

GOVINDAIAH, B., SHANKARANARAYANA, S. and RAJU, T.R. (2002). Enhanced metabolic activity coincides with survival and differentiation of cultured retinal ganglion cells exposed to glutamate. Neurosci. 113:547-553.

GRÜNDER, T., KOHLER, K. KALETTA, A. and GUENTHER, E. (2000). The distribution and developmental regulation of NMDA receptor subunit proteins in the outer and inner retina of the rat. J Neurobiol. 44:333-342.

HAHM, J.O. LANGDON, R.B. and SUR, M. (1991). Disruption of retinogeniculate afferent segregation by antagonists to NMDA receptors. Nature. 351:568-570.

HAHM, J.O., CRAMER, K.S. and SUR, M. (1999). Pattern formation by retinal afferents in the ferret lateral geniculate nucleus: developmental segregation and the role of N-methyl-D-aspartate receptors. J Comp Neurol. 412:705-7.

HERMES, B., REUSS, S. and VOLLRATH, M. (1992). Synaptic ribbon, spheres and intermediate structures in the developing rat retina. Int. J. Dev. Neurosci. 134:116

HOFFMAN, P.L., RABE, C.S., MOSES, F. and TABAKOFF, B. (1989) N-methyl-Daspartate receptors and ethanol: inhibition of calcium flux and cyclic GMP production. J Neurochem. 52:1937-40.

HOLLMANN, M. and HEINEMANN, S. (1994). Cloned glutamate receptors. Ann Rev Neurosci. 17:31-108.

IKONOMIDOU, C., BOSCH, F., MIKSA, M., BITTIGAU, P., VÖCKLER, J., DIKRANIAN, K., TENKOVA, T.I., STEFOVSKA, V., TURSKI, L. and OLNEY, J.W. (1999). Blockade of NMDA receptors and apoptotic neurodegeneration in the developing brain. Science. 283:70-74.

INSAUSTI, R., BLAKEMORE, C., COWAN, W.M. (1984). Ganglion cell death during development of ipsilateral retino-collicular projection in golden hamster. Nature 308: 362-365.

KUWABARA, T. and WEIDMAN, T.A. (1974). Development of the prenatal rat retina. Invest Ophthalmol. 13:725-739.

LAUBE, B., KUHSE, J. and BETZ, H. (1998). Evidence for a tetrameric structure of recombinant NMDA receptors. JNeurosci. 18:2954-2961.

LAUDER, J.M. (1993). Neurotransmitters are growth regulatory signals: role of receptors and second messengers. Trends Neurosci. 16:233-240.

LOVINGER, D.M., WHITE, G. and WEIGHT, F.F. (1989). Ethanol inhibits NMDAactivated ion current in hippocampal neurons. Science. 243:1721-4.

MAFFEI, L. and GALLI-RESTA, L. (1990). Correlation in the discharges of neighboring rat retinal ganglion cells during prenatal life. Proc Natl Acad Sci USA. 87:2861-2864.

MARTIN, P., SCHIMIDT, R.E., DI STEFANO, P.S., LOWRY, O.H., CARTER, J.G. and JOHNSON, E.M. (1996). Inhibitors of protein synthesis and RNA synthesis prevent neuronal death caused by nerve growth factor deprivation. J. Cell Biol. 106:829-844.

MARTINS, R.A., SILVEIRA, S.M., CURADO, M.R., POLICE, A.I. and LINDEN, R.
(2005). NMDA receptor activation modulates programmed cell death during early post-natal retinal development: a BDNF-dependent mechanism. JNeurochem. 95:244-53.

MASSEY, S.C. (1990) Cell types using glutamate as a neurotransmitter in the vertebrate retina. Prog Ret Res. 9: 399-425.

MONYER, H., BURNASHEV, N., LAURIE, D.J., SAKMANN, B., SEEBURG, P.H. (1994). Developmental and regional expression in the rat brain and functional properties of four NMDA receptors. Neuron 12:529 -540.

MORI, H. and MISHINA, M. (1995). Neurotransmitter receptors. Structure and function of NMDA receptor channel. Neuropharmacol. 34:1219-1237.

NICOLETTI, F., BRUNO, V., COPANI, A., CASABONA, G. and KNOPFEL, T. (1996). Metabotropic glutamate receptors: a new target for the therapy of neurodegenerative disorders? Trends Neurosci. 19:267-271.

NARDI, A.R., WANG, H., QIN, Y., LABRUYERE, J., OLNEY, J.W. and YOUNG, C. (2004). Memantine induces neuroapoptosis in the developing mouse retina. Program No.219.4 Abstract. Washington, DC: Society for Neuroscience.

PERRY, V.H., HENDERSON, Z. and LINDEN, R. (1983). Postnatal changes in retinal ganglion cell and optic axon populations in the pigmented rat. J Comp Neurol. 219: 356-368.

PERRY, V.H. and COWEY, A. (1979). The effects of cortical and tectal lesions on retinal ganglion cells in rat. Exp Brain Res. 9:85-95.

REDBURN, D.A. and ROWE-RENDLEMAN, C. (1996). Developmental neurotransmitters: signals for shaping neuronal circuitry. Invest Ophthalmol Vis Sci. 37:1479-1482.

ROCHA, M., MARTINS, R.A. and LINDEN, R. (1999). Activation of NMDA receptors protects against glutamate neurotoxicity in the retina: evidence for the involvement of neurotrophins. Brain Res. 827:79-92.

ROSENMUND, C., STERN-BACH, Y. and STEVENS, C.F. (1998). The tetrameric structure of a glutamate receptor channel, Science. 280:1596-1599.

SIMON, D.K., PRUSKY, G.T., O'LEARY, D.D. and CONSTANTINE-PATON, M. (1992). N-methyl-D-aspartate receptor antagonists disrupt the formation of a mammalian neural map. Proc Nat/ Acad Sci USA. 89:10593-10597.

STROMLAND, K. and PINAZO-DURAN, M.D. (1994). Optic nerve hypoplasia: comparative effects in children and rats exposed to alcohol during pregnancy. Teratology. 50:100-11.

TENKOVA, T., YOUNG, C., DIKRANIAN, K., LABRUYERE, J. and OLNEY, J.W. (2003). Ethanol-induced apoptosis in the developing visual system during synaptogenesis. Invest Ophthalmol Vis Sci. 44:2809-17.

VECINO, E., HERNANDEZ, M. and GARCIA, M. (2004). Cell death in the developing vertebrate retina. Int J Dev Biol. 48:965-74. (http://dx.doi.org/10.1387/ ijdb.041891ev)

VOGEL, M. and MÖLLER, K. (1980). Cellular decay in the rat retina during normal post-natal development: A preliminary quantitative analysis of the basic endogenous rhythm. Albrecht von Graefes Arch Klin Exp Ophthalmol. 212:243-260.

WATANABE, M., INOUE, Y., SAKIMURA, K. and MISHINA M. (1992). Developmental changes in distribution of NMDA receptor channel subunit mRNAs. NeuroReport. 3:1138-1140.

WEIDMAN, T.A. and KUWABARA, T. (1968). Postnatal development of the rat retina. An electron microscopic study. Arch Ophthalmol. 79:470-484.

WEIDMAN, T.A. and KUWABARA, T. (1969). Development of the rat retina. Invest. Ophthalmol. Vis. Sci. 8:60-69

WONG, K., LIU, X.B., MATOS, M.F., CHAN, S.F., PEREZ-OTANO, I., BOYSEN, M., CUI, J., NAKANISHI, N., TRIMMER, J.S., JONES, E.G., LIPTON, S.A. and SUCHER, N.J. (2002). Temporal and regional expression of NMDA receptor subunit NR3A in the mammalian brain. J Comp Neurol. 450:303-317.

Received: 9th June 2006

Reviewed by Referees: 27th July 2006

Modified by Authors and Accepted for Publication: 31st October 2006

Published Online: 17th November 2006 